To Maega | JurnalPengabdianMasyarakat

Bulan-Tahun, Vol.3, No.2, hal. 104-110

$\operatorname{ISSN}(P): 2622-6332 ; \operatorname{ISSN}(E): 2622-6340$

http://www.ojs.unanda.ac.id/index.php/tomaega

\title{
Meningkatkan Pemahaman Akan Pengendalian OPT Bawang Putih Pada Anggota Kelompok Tani Ngudi Rahayu
}

\author{
Puguh Bintang Pamungkas 1,a, , Ardiyanta 2,b \\ 1,2 Program Studi Agroteknologi, Fakultas Pertanian, Universitas PGRI Yogyakarta \\ a,bEmail:puguhbintang4478@gmail.com; ir.ardiyanta@gmail.com \\ *Correspondent Email:puguhbintang4478@gmail.com \\ Article History: \\ Received: 2-7-2020; Received in Revised: 9-7-2020; Accepted: 21-7-2020 \\ DOI: http://dx.doi.org/10.35914/tomaega.v3i2.380
}

\begin{abstract}
Abstrak
Bawang putih (Allium sativum L.)memiliki begitu banyak manfaat, dimana seharusnya diikuti dengan peningkatan akan produktivitasnya. Namun dilapangan budidaya bawang putih belum mampu mencukupi permintaan dari pasar, sehingga dilakukan import untuk memenuhinya. Banyak faktor yang menyebabkan rendahnya produktivitas bawang putih, mulai dari kualitas bibit yang rendah, sampai gangguan OPT (organisme pengganggu tanaman). Pengendalian OPT (organisme pengganggu tanaman) yang tepat juga akan membantu peningkatan produktivitas bawang putih, dimana pengendalian bisa dilakukan dengan mengidentifikasi terlebih dahulu OPT yang menyerang. Kemudian dilakukan pengendalian secara kultur teknis, maupun penggunaan agen hayati. Oleh karena itu, dilakukan penyuluhan/sosialisasi mengenai pengenalan dan pengendalian OPT bawang putih, (baik di lahan maupun di gudang pasca panen) yang diikuti oleh anggota Kelompok Tani Ngudi Rahayu, Cepit, Pagergunung, Kec. Bulu, Kab. Temanggung, Jawa Tengah. Berdasarkan, hasil kegiatan penyuluhan, pengetahuan petani akan pengenalan dan pengendalian OPT meningkat sebesar 39\% dibandingkan sebelum adanya kegiatan penyuluhan. Dari kegiatan yang telah dilakukan dapat disimpulkan bahwa petani melakukan pengendalian dengan cara yang telah dilakukan turun-temurun, pemahaman petani akan pengendalian OPT mengalami peningkatan setelah kegiatan sosialisasi, oleh karena itu perlu dilakukan pendampingan secara berkala kepada petani, sehingga hasil penyuluhan dapat memberikan damapak nyata terhadap peningkatan produksi bawang putih.
\end{abstract}

Kata Kunci: bawang putih, kelompok tani, opt, sosialisasi

\section{Abstract}

Garlic (Allium sativum L.) has so many benefits, which should be followed by an increase in productivity. But in the field of garlic cultivation has not been able to meet the demand of the market, so do import to fulfill. Many factors cause low productivity of garlic, starting from low quality seeds, to pest and disease disorders. Proper pest control will also help increase the productivity of garlic, where control can be done by identifying the pest first. Then the technical culture is controlled and the use of biological agents. Therefore, socialization was carried out regarding the introduction and control of garlic pests (both on land and in the post harvest warehouse) which was followed by members of the Ngudi Rahayu Farmer Group, Cepit, Pagergunung, Bulu, Temanggung, Central Java. Based on the results of extension activities, knowledge and farmers will be the introduction of the pest control increased by 39\% compared to before their extension activities. From the activities that have been carried out it can be concluded that farmers carry out control in a way that has been carried down for generations, farmers' 
[ 105 ] Puguh Bintang Pamungkas, dkk / To Maega : Jurnal Pengabdian Masyarakat, Vol.3; No.2; Agustus, 2020

understanding of pest control has increased after socialization activities, therefore it is necessary to provide periodic assistance to farmers, so that the results of counseling can have a real impact on increasing garlic production.

Key Word: Farmers, garlic, pest, socialization

\section{Pendahuluan}

Bawang putih (Allium sativum L.) merupakan salah satu sayuran yang sering digunakan sebagai bumbu penyedap masakan. Santoso (1988) menyatakan bahwa bawang putih juga sering digunakan untuk kosmetik serta bahan obat. Song (2001) juga menyatakan banyak penelitian menunjukkan efek farmakologis bawang putih seperti anti bakteri, anti jamur, anti kanker, antioksidan, hipolipidemik, dan hipoglikemik.

Menurut Badan Pusat Statistik (2018), data luas panen bawang putih dari tahun 2009 s.d 2018 mengalami peningkatan dari 2.293 Ha menjadi 5.013 Ha, sedangkan produksi di rentang waktu yang sama juga mengalami peningkatan dari 15.419 ton menjadi 39.301 ton. Namun, ternyata data impor bawang putih di tahun 2018 dinilai masih tinggi yakni sebesar 582.990 ton. Produksi bawang putih dalam negeri hanya memenuhi 5\% dari kebutuhan nasional, sedangkan 95\% kekurangannya masih dipenuhi oleh impor.

Banyak faktor yang menjadi permasalahan rendahnya produksi bawang putih diantaranya karena luas lahan dan produktivitas yang rendah. Selain itu menurut Wibowo (2006) kualitas bibit bawang putih yang digunakan juga rendah, sehingga menyebabkan bibit bawang putih terserang beberapa penyakit, seperti terkena jamur dan virus.

Salah satu alternatif yang bisa dilakukan untuk meningkatkan produksi dan hasil tanaman bawang putih adalah teknik budidaya yang tepat seperti penggunaan varietas unggul dan bersertifikat, pemupukan berimbang, pengendalian OPT secara tepat, menggunakan mikroorganisme yang menguntungkan, dll.

Umumnya pengendalian yang dilakukan oleh petani menggunakan varietas tahan maupun pestisida kimiawi secara turun temurun. Usaha tersebut belum mencapai hasil memuaskan, karena penggunaan pestisida kimiawi memiliki kelemahan bila digunakan dalam jangka panjang. Pengendalian dengan agen hayati dapat menghindari efek samping yang tidak diinginkan dari penggunaan pestisida, karena pengendalian secara biologi dinilai tidak merusak lingkungan dan tidak menimbulkan efek fitotoksitas. Pengendalian hayati merupakan usaha untuk memanfaatkan dan menggunakan mikroorganisme antagonis sebagai pengendali populasi patogen.

Pengendalian hama dan penyakit yang tepat akan mampu meningkatkan produksi dari bawang putih, pengendalian dapat dilakukan dengan cara mengenali terlebih dahulu organisme penggangunya. Untuk itu dilakukan kegiatan pengenalan serta pengendalian OPT di Kelompok Tani Ngudi Rahayu, Kec. Bulu, license (https://creativecommons.org/licenses/by-sa/4.0/). 
[ 106 ] Puguh Bintang Pamungkas, dkk / To Maega : Jurnal Pengabdian Masyarakat, Vol.3; No.2; Agustus, 2020

Kab. Temanggung, Jawa Tengah. Diharapkan melalui kegiatan ini dapat meningkatkan pemahaman petani mengenai OPT bawang putih dan pengendaliannya, serta diharapkan dapat meningkatkan produktivitas bawang putih di kelompok tersebut.

\section{Metode}

Kegiatan tim pelaksanaan kepada masyarakat ini bertujuan untuk membantu mitra dalam mengatasi permasalahan yang dihadapi. Langkah-langkah yang ditempuh untuk mencapai tujuan tersebut adalah sebagai berikut:

1. Melakukan diskusi dengan mitra untuk mengetahui permasalahan yang dihadapi oleh mitra. Berdasarkan hasil diskusi tersebut dapat diidentifikasi permasalahan-permasalahan yang dihadapi oleh mitra. Selanjutnya tim pelaksana dan mitra sepakat memilih permasalahan yang akan diselesaikan melalui kegiatan tim pelaksanaan kepada masyarakat dan merumuskan solusi terpilih. Kegiatan ini dilakukan sebelum penyusunan proposal.

2. Melakukan koordinasi dengan ketua kelompok tani untuk menentukan waktu dan areal pelaksanaan kegiatan.

3. Melaksanakan penyuluhan tentang pengenalan \& pengendalian OPT bawang putih baik di lahan maupun di gudang (pasca panen). Kegiatan ini dilakukan kepada anggota Kelompok Tani Ngudi Rahayu yang bertempat di Lereng Gunung Sumbing, Kec. Bulu, Kab. Temanggung. Materi penyuluhan yang diberikan meliputi materi pengenalan \& pengendalian OPT bawang putih baik di lahan maupun di gudang (pasca panen) bawang putih. Kegiatan ini dimaksudkan agar mitra memiliki pengetahuan dan ketrampilan dalam pengendalian OPT bawang putih, sehingga mampu mengurangi kerugian yang ditimbulkan oleh OPT.

4. Melakukan pendampingan. Kegiatan ini dilaksanakan untuk menjamin keberlangsungan program dan memastikan mitra dapat melaksanakan kegiatan seperti yang telah direncanakan.

\section{Hasil dan Pembahasan}

Kegiatan tim pelaksanaan ini diawali dengan tahapan survei dan koordinasi dengan mitra yang dilakukan pada tanggal 2 Maret 2020, dalam hal ini tim pelaksana melakukan koordinasi bersama Kelompok Tani Ngudi Rahayu, Cepit, Pagergunung, Kec. Bulu, Kab. Temanggung, Jawa Tengah. Hasil dari koordinasi dengan mitra. Tim pelaksana akan memberikan penyuluhan/sosialisasi kepada anggota Poktan Ngudi Rahayu mengenai pengenalan dan pengendalian OPT bawang putih, baik OPT di lahan maupun di gudang.

Saat penyuluhan berlangsung pada tanggal 7 Maret 2020, yang menjadi peserta adalah anggota Poktan Ngudi Rahayu. Peserta begitu antusias dengan materi yang disampaikan, karena ada beberapa lahan petani yang terkena OPT 
[ 107 ] Puguh Bintang Pamungkas, dkk / To Maega : Jurnal Pengabdian Masyarakat, Vol.3; No.2; Agustus, 2020

walaupun sudah dilakukan pengendalian masih belum terlihat berkurangnya serangan OPT tersebut. Sehingga, proses pengenalan OPT ini sangat penting untuk petani dalam melakukan pengendalian, agar tanaman bawang putih yang dibudidayakan tidak habis akibat serangan OPT dan produktivitas bawang putih juga tetap tinggi.

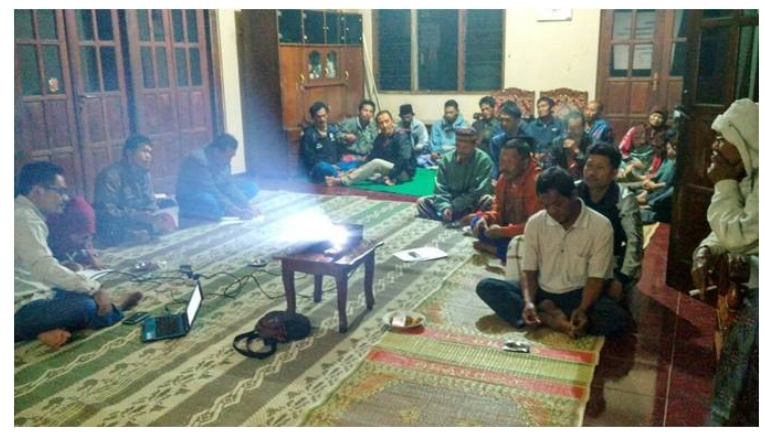

Gambar 1. Pelaksanaan Kegiatan

Ketika penyuluhan berlangsung disampaikan mengenai bermacam-macam proses pengendalian OPT mulai dari kultur teknis, penggunaan agen hayati, hingga pengendalian kimiawi. Para pesertapun dibekali pengetahuan, jika pengendalian OPT tidak serta merta menggunakan produk kimiawi yang sudah beredar dipasaran. Namun, alangkah lebih baiknya dilakukan secara kultur teknis/pengendalian hayati terlebih dahulu, kemudian penggunaan produk kimiawi dapat diberikan pada pilihan terakhir dalam proses pengendalian dengan memperhatikan kaidah 6T (Tepat dosis, tepat waktu, tepat aplikasi, tepat cara, dan tepat sasaran).

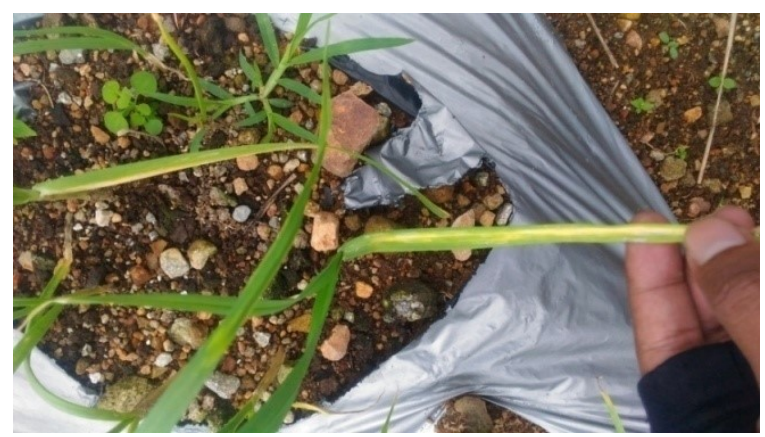

Gambar 2. Tanaman bawang putih terserang OPT

Pengetahuan mengenai pengendalian alternatif sangat penting agar petani tidak bergantung pada penggunaan produk kimiawi. Hal ini akan memberikan dampak positif dari segi ekonomi petani dan dari segi kesehatan tanah, dimana biaya produksi untuk penggunaan pestisida dapat ditekan dan tanah tempat budidaya juga lebih sehat dengan tidak terkena residu dari penggunaan bahan kimiawi dari pestisida maupun fungisida.

Penggunaan pengendalian alternatif yang diberikan ada 2 macam, yakni penggunaan likat kuning dan tricoderma. Likat kuning (yellow sticky trap) digunakan untuk upaya preventif dalam pengendalian hama (Sulistyo, R. 2016). Serangga umumnya tertarik dengan cahaya, warna, aroma makanan atau bau 
[ 108 ] Puguh Bintang Pamungkas, dkk / To Maega : Jurnal Pengabdian Masyarakat, Vol.3; No.2; Agustus, 2020

tertentu, dimana warna yang disukai serangga biasanya warna-warna kontras seperti warna kuning cerah. Serangga mempunyai dua alat detector yang penerima rangsang cahaya yaitu mata tunggal (oseli) dan mata majemuk (omatidia).

Penggunaan perangkap likat kuning dilaporkan dapat menekan vektor dan penyakit virus pada tanaman cabai (Gunaeni, dkk. 2014). Menurut (Holmer et al. 2008), perangkap likat kuning dapat menekan dan memonitor serangan atau perpindahan kutu kebul di lapangan dan memprediksi bahaya infeksi virus.

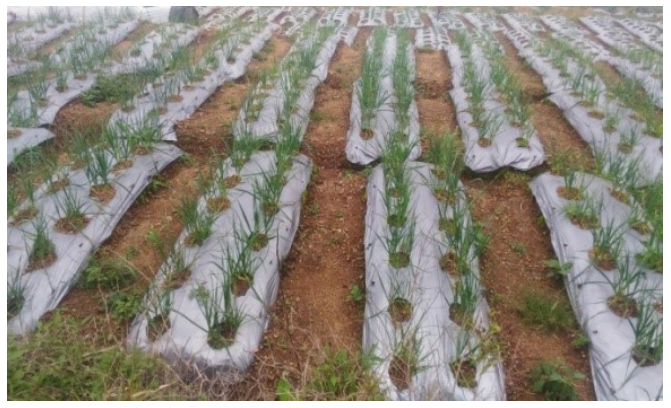

Gambar 3. Kondisi lahan budidaya bawang putih belum terpasang likat kuning

Penggunaan trichoderma, sp selain sebagai agen hayati, dapat juga berfungsi sebagai organisme pengurai dan stimulator pertumbuhan tanaman. Trichoderma, sp dapat menghambat pertumbuhan serta penyebaran racun jamur penyebab penyakit bagi tanaman seperti cendawan Rigdiforus lignosus, Fusarium oxysporum, Rizoctonia solani, Fusarium monilifome, Sclerotium rolfsii dan cendawan Sclerotium rilfisil (Farida, et al. 2017).

Selain memberikan informasi mengenai materi penyuluhan tentang pengenalan dan pengendalian OPT bawang putih. Tim pelaksana juga mendapatkan feedback dari peserta penyuluhan berupa angket yang berisi beberapa pernyataan sebelum dan setelah penyuluhan dilakukan.

Tabel 1. Data perbandingan rata-rata nilai setiap pernyataan angket sebelum dan sesudah penyuluhan

\begin{tabular}{clcc}
\hline No & \multicolumn{1}{c}{ Pernyataan } & $\begin{array}{c}\text { Sebelum } \\
\text { penyuluhan }\end{array}$ & $\begin{array}{c}\text { Setelah } \\
\text { penyuluhan }\end{array}$ \\
\hline 1 & Pengetahuan macam OPT & 2.50 & 3.00 \\
\hline 2 & $\begin{array}{l}\text { Pengetahuan macam pengendalian } \\
\text { OPT }\end{array}$ & 2.36 & 3.00 \\
\hline 3 & $\begin{array}{l}\text { Pengetahuan pengendalian kultur } \\
\text { teknis }\end{array}$ & 2.00 & 2.95 \\
\hline 4 & Pengetahuan pengendalian hayati & 1.68 & 3.00 \\
\hline 5 & $\begin{array}{l}\text { Pengetahuan pengendalian kimiawi } \\
\text { Kaidah 6T) }\end{array}$ & 2.05 & 2.91 \\
\hline 6 & Pengetahuan likat kuning & 1.50 & 2.95 \\
\hline 7 & Pengetahuan trichoderma & 1.09 & 2.82 \\
\hline 8 & Pengetahuan panen & 3.00 & 3.00 \\
\hline 9 & Pengetahuan pasca panen & 2.00 & 3.00 \\
\hline
\end{tabular}


[ 109 ] Puguh Bintang Pamungkas, dkk / To Maega : Jurnal Pengabdian Masyarakat, Vol.3; No.2; Agustus, 2020

Angket yang diberikan kepada petani ini diberikan ketika sebelum dan setelah penyuluhan berlangsung, dimana skala nilai yang ada mulai dari skala 1 untuk kategori belum mengetahui, skala 2 untuk kategori cukup mengetahui dan skala 3 untuk kategori sudah mengetahui.

Rata-rata nilai angket ketika sebelum penyuluhan diberikan ialah 2.02 dan setelah penyuluhan diberikan mengalami peningkatan sebesar 47\% menjadi 2.96 . Nilai yang menunjukkan kenaikan cukup drastis adalah pernyatan no.7 dari skala 1.09 menjadi 2.82, dimana petani yang sebelum penyuluhan belum memiliki cukup pengetahuan akan trichoderma. Namun setelah kegiatan penyuluhan, pengetahuan petani bertambah akan trichoderma, dimana trichoderma dapat digunakan untuk pengurai tanah hingga sebagai agen hayati (Farida, et al. 2017).

\section{Kesimpulan}

Berdasarkan kegiatan sosialisasi mengenai pengenalan dan pengendalian OPT bawang putih, yang telah dilaksanakan di Kelompok Tani Ngudi Rahayu, Cepit, Pagergunung, Kec. Bulu, Kab. Temanggung, Jawa Tengah, dapat disimpulkan bahwa pengendalian OPT yang dilakukan petani pada awalnya hanya mengunakan metode turun-temurun, kemudian setelah diberikan sosialisasi mengenai pengenalan dan pengendalian OPT beserta metode alternatifnya, pengetahuan petani bertambah dibandingkan dengan sebelum sosialisasi.

Berdasarkan evaluasi dari kegiatan yang telah dilakukan, dapat diberikan saran untuk kegiatan selanjutnya ialah pendampingan yang intensif agar petani dapat konsisten menerapkan metode pengendalian dengan efektif dan efisien, seperti penggunaan likat kuning maupun trichoderma.

\section{Daftar Pustaka}

BPS. 2018. Statistik Tanaman Sayuran dan Buah-buahan Semusim Indonesia 2017. Badan Pusat Statistik. Jakarta.

Farida, Neneng Ida. 2017. Manfaat dan Cara Pembuatan Biofungisida Trikoderma.Balai Besar Pelatihan Pertanian Lembang. Lembang.

Gunaeni, N, Setiawati, W, dan Kusandriani, Y. 2014. Pengaruh Perangkap Likat Kuning, Ekstrak Tagetes erecta, dan Imidacloprid Terhadap Perkembangan Vektor Kutukebul dan Virus Kuning Keriting Pada Tanaman Cabai Merah (Capsicum annuum L.). J. Hort. 24(4): 346-354, 2014.

Holmer, K \& Simmons, AM 2008, Yellow Sticky Traps Catches of Parasitoid of Bemisia tabaci (Hemiptera: Aleyrodidae) in Vegetable Crops and Their Relationship to in Field Populations, J. Environ. Ento, vol. 37, no. 2

Santoso, H.B. 1988. Bawang Putih. Yogyakarta: Kanisius 
[ 110 ] Puguh Bintang Pamungkas, dkk / To Maega : Jurnal Pengabdian Masyarakat, Vol.3; No.2; Agustus, 2020

Song, K. and J. A. Milner. 2001. The Influence Of Heating On The Anticancer Properties Of Garlic. Journal of Nutrition, Vol. 131. Hal: 1054S - 1057S.

Sulistyo, Rais Widiyatmoko. 2016. Perangkap Likat Kuning (yellow sticky trap) Teknologi Pengendalian OPT Cabai Ramah Lingkungan. http://distan.jogjaprov.go.id/perangkap-likat-kuning/. Diakses 15 Juni 2020.

Wibowo, Singgih. 2006. Budidaya Bawang Merah, Bawang Putih, dan Bawang Bombay. Penebar Swadaya. Jakarta, $194 \mathrm{hlm}$. 